\title{
TERRA SIGILLATA V KONTEXTE SÍDLISKA PRZEWORSKEJ KULTÚRY V TRSTENOM PRI HORNÁDE ${ }^{1}$
}

\author{
Klára Kuzmová - Ján Rákoš
}

DOI: https://doi.org/10.31577/szausav.2019.suppl.1.18

Keywords: Terra sigillata, settlement, Przeworsk culture, $2^{\text {nd }}-3^{\text {rd }}$ century, East Slovakia

\section{Terra sigillata in the context of a Przeworsk culture settlement at Trstené pri Hornáde}

Terra sigillata from Trstené pri Hornáde represents the largest collection of this type of pottery from the territory of present-day eastern Slovakia (28 pcs). Part of it has been published earlier, and the collection has recently been reevaluated in a new complex treatment of the associated Przeworsk culture settlement. The new analysis shows that the finds come from four production centres (Lezoux, Rheinzabern, Westerndorf and Pfaffenhofen) and likely found their way to this part of Barbaricum through Pannonia. The finds prove the existence of contacts between the natives and the Romans roughly in the period between the second half of the $2^{\text {nd }}$ and the first half of the $3^{\text {rd }}$ century AD, with the most intensive contacts in the Severan period. In terms of the settlement context, terra sigillata derives from three stratigraphically defined layers and five structures of different types, function and dating: from the Early to the Late Roman period, or even as late as the beginning of the Migration period (stages B2/C1-C3-D). A comparison between the dating of terra sigillata and that of the other finds from the structures has been conducted and its results will form a basis for further research.

\section{ÚVOD}

Sídlisko przeworskej kultúry v Trstenom pri Hornáde (okr. Košice a okolie) sa nachádza približne $1 \mathrm{~km}$ severne od centra dnešnej obce, vo vzdialenosti asi $1,5 \mathrm{~km}$ od štátnej hranice s Mad’arskom. Leží na južnom okraji Košickej kotliny, v mieste jej styku so Slanskými vrchmi, na mierne vyvýšenej lavobrežnej terase rieky Hornád (200 m n. m.). Ide o polykultúrnu lokalitu, ktorej osídlenie v dobe rímskej spadá od 2. po začiatok 5. stor., ked’ bolo toto územie súčastou barbarika. Archeologický výskum sa tu uskutočnil v rokoch 1980-1984 pod vedením PhDr. Pavla Jurečka, pracovníka Východoslovenského múzea v Košiciach, a jeho výsledky boli priebežne publikované (Jurečko 1981; 1982a; 1983; Kol. AOVM 1984). Zo sídliska pochádza početný súbor nálezov, medzi ktorými nechýbajú ani rímskoprovinciálne výrobky (úžitková keramika, terra sigillata, spony, mince; súhrnne Kuzmová/Rákoš 2016), využitelné aj pri časovom zaradení sprievodných nálezov a príslušných archeologických štruktúr. Rámcovo spadajú do obdobia od druhej polovice 2. stor. do prvej polovice 3. stor., ked' bolo nálezisko osídlené nositelmi przeworskej kultúry, ktorí obývali areál až do začiatku 5. stor. Ich významnou súčastou je súbor terry sigillaty pozostávajúci z 28 fragmentov, ktorých čast̉ bola už v minulosti určená a publikovaná (Jurečko 1983, 291, 304, obr. 24: 3; 40: 3; 42: 5; 47: 4-6, 8, 11; 55: 2; Kuzmová 2014, 172, 173, tabela 1; 2; Kuzmová/Rákoš 2016; Kuzmová/Roth 1988, 113, 114, obr. 26: 8-11; pozri tiež Ardeleanu 2014, 12, tabela 1). Pri novom, komplexnom spracovaní osídlenia lokality v dobe rímskej sa pristúpilo aj k novému spracovaniu a vyhodnoteniu terry sigillaty podla súčasných poznatkov bádania o tejto keramike, ktorá sa zároveň skúmala v príslušnom nálezovom kontexte. V príspevku, ktorý s úctou venujeme PhDr. Elene Miroššayovej, CSc., predkladáme jeho aktuálne výsledky.

Z analýzy súboru terry sigillaty v prvom rade vyplynulo, že pozostáva z výrobkov štyroch produkčných centier, ktorými sú Lezoux, Rheinzabern, Westerndorf a Pfaffenhofen. 


\section{TERRA SIGILLATA Z TRSTENÉHO PRI HORNÁDE}

\section{Výrobky zo strednej Galie, Lezoux (kat. č. 1-7; tab. I: 1-4)}

Terra sigillata zo strednej Galie (7ks, 25 \% všetkých nálezov) patrí k najvčasnejším nálezom skúmaného súboru. V rámci nej výrazne prevažujú fragmenty reliéfne zdobených misiek typu Drag. $37(5 \mathrm{ks})^{2} \mathrm{z}$ druhej polovice 2. stor., presnejšie z antoninovského až neskoroantoninovského obdobia. Dva z nich boli určené ako výrobky Cinnama (datované medzi roky 145-170/178; kat. č. 1; 2; tab. I: 1, 2) a dva dalšie boli pravdepodobne vyrobené v dielni Albucia (medzi rokmi 150-180; kat. č. 3; 4; tab. I: 3, 4). Výrobky uvedených majstrov pôsobiacich $\mathrm{v}$ hrnčiarskom centre Lezoux sú dôležité z chronologického i historického hladiska, kedže v Panónii sú doložené v tzv. zánikových horizontoch spájaných s udalost’ami markomanských vojen (Gabler 2002, 230; 2012a, 123; 2017, 31, obr. 10). Dva d’alšie zlomky, z nezdobených častí reliéfnej sigillaty, nie sú bližšie datovatelné (kat. č. $5 ; 6$; tab. IV: 12), a podobne ani fragment hladkej sigillaty (Drag. 33; kat. č. 7), ktorý je jediným nálezom tohto druhu v rámci celého súboru. ${ }^{3}$

Pri celkovom datovaní sigillaty z Lezoux sa možno opriet’ najskôr o nálezy z Panónie, prostredníctvom ktorej sa tieto výrobky dostávali do prilahlého barbarika. Ťažiskom ich výskytu je druhá polovica 2. stor., pričom sa za jeho hornú hranicu považuje záver markomanských vojen (rok 180), ked’ doznievala ich masová distribúcia do tejto provincie (Gabler/Márton/Gauthier 2009, 214, obr. 7).

Uvedené nálezy z Trsteného pri Hornáde pochádzajú prevažne z povrchovej vrstvy, iba po jednom exemplári zo sídliskovej vrstvy A a z objektu 18 (tabela 1; 2; ku kontextu pozri nižšie). Okrem tejto lokality je stredogalská terra sigillata evidovaná aj na d’alších troch sídliskách východného Slovenska, z nich jeden fragment sa spája priamo s dielňou Cinnama (Kuzmová 2014, 171).

Tabela 1. Trstené pri Hornáde, okr. Košice okolie. Prehl’ad terry sigillaty zo sídliskových vrstiev.

\begin{tabular}{|c|c|c|c|c|c|}
\hline & Dielňa & Typ nádoby & Majster & Datovanie & Kat. č. \\
\hline \multirow{5}{*}{ 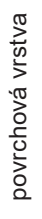 } & Lezoux & Drag. 37 & Cinnamus & 2. pol. 2. stor.(145-170/178) & 1 \\
\hline & Lezoux & Drag. 37 & Cinnamus (?) & 2. pol. 2. stor.(145-170/178) & 2 \\
\hline & Lezoux & Drag. 37 & Albucius (?) & 2. pol. 2. stor.(150-180) & 4 \\
\hline & Rheinzabern & Drag. 37 & Janu(arius) I, Cerialis, I, III, V, Comitialis I, II & 2. pol. 2.-1. tret. 3. stor. & 8 \\
\hline & Westerndorf & Drag. 37 & Helenius & 1. tret. 3. stor. & 26 \\
\hline \multirow{6}{*}{ 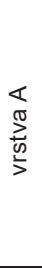 } & Lezoux & Drag. 37 & Albucius (?) & 2. pol. 2. stor.(150-180) & 3 \\
\hline & Lezoux & Drag. $30,37 ?$ & $?$ & 2. pol. 2. stor.(150-180) & 6 \\
\hline & Rheinzabern & Drag. 37 & Cerialis I, Comitialis I, B. F. Attoni & $180-220 / 230$ & 10 \\
\hline & Rheinzabern & Drag. 37 & Atto, Reginus II & $190 / 200-230$ & 14 \\
\hline & Westerndorf & Drag. 37 & Comitialis (Decminus) & koniec 2.-zač. 3. stor. & 25 \\
\hline & Westerndorf & Drag. 37 & $?$ & koniec 2.-1. tret. 3. stor. & 27 \\
\hline \multirow{6}{*}{$\begin{array}{l}\infty \\
\sum_{\infty}^{\infty} \\
\stackrel{\infty}{>}\end{array}$} & Lezoux & Drag. 33 & $?$ & 2. pol. 2. stor.(150-180) & 7 \\
\hline & Rheinzabern & Drag. 37 & Cobnertus III, Attilus, Primitivus I & $160-220 / 230$ & 9 \\
\hline & Rheinzabern & Drag. 37 & Cerialis I, Belsus I & $180-220$ & 11 \\
\hline & Rheinzabern & Drag. 37 & Cerialis I, V, B.F.Attoni & $180-220 / 230 ?$ & 12 \\
\hline & Rheinzabern & Drag. 37 & Augustinus III & koniec 2. stor. & 15 \\
\hline & Westerndorf & Drag. 37 & Comitialis (Decminus) & koniec 2.-zač. 3. stor. & 24 \\
\hline
\end{tabular}

Výrobky z Rheinzabernu (kat. č. 8-22; tab. I: 5-12; II: 1, 2; III: 11, 19-21; IV: 15)

Zo všetkých produkčných centier sú v Trstenom pri Hornáde najpočetnejšie výrobky z Rheinzabernu (14 ks; 50 \%), ktoré sú fragmentmi výlučne reliéfne zdobených misiek (Drag. 37). Viac ako polovica z nich (9 ks) bola bližšie identifikovaná. Na základe výzdobných prvkov sa však niektoré nálezy môžu

\footnotetext{
2 V prípade d’alšieho fragmentu nemožno jednoznačne určit či ide o tvar Drag. 30, alebo Drag. 37.

3 Pôvodne sa predpokladalo, že tento fragment bol vyrobený v južnej Galii v období vlády Domitiana až Hadriana (Kuzmovál Roth 1988, 113; pozri tiež Kuzmová 2014, 171). Pri novej analýze sa však zistilo, že ide skôr o stredogalskú sigillatu z antoninovského obdobia, presnejšie z druhej polovice 2. stor.
} 
pripísat viacerým hrnčiarom, preto je ich datovanie pomerne široké. Po jednom exemplári sú medzi nimi zastúpené nasledovné dielne:

Janu(arius) I, Cerialis I, III, V alebo Comitialis I, II (kat. č. 8; tab. I: 5);

Cobnertus III, Attilus alebo Primitivus I (kat. č. 9; tab. I: 6) ${ }^{4}$;

Cerialis I, Comitialis I alebo B. F. Attoni (kat. č. 10; tab. I: 7);

Cerialis I alebo Belsus I (kat. č. 11; tab. I: 8);

Cerialis I, V alebo B. F. Attoni (kat. č. 12; tab. I: 9);

Belsus I (kat. č. 13; tab. I: 10; III: 11);

Atto alebo Reginus II (kat. č. 14; tab. I: 11);

Augustinus III (kat. č. 15; tab. I: 12);

Verecundus I (kat. č. 16; tab. II: 1).

Vyskytujú sa medzi nimi aj mená hrnčiarov spájaných s prvým produkčným obdobím v Rheinzaberne, datovaným medzi roky 150-180 (napr. Janu[arius] I, Cobnertus III, Cerialis I, III, V, Belsus I), pričom výrobky niektorých z nich sú doložené aj v zánikových vrstvách spájaných s markomanskými vojnami (Cobnertus, Cerialis; Gabler 2017, 31, obr. 10). Ďalších pät nálezov vyrobených v Rheinzaberne nemožno bližšie identifikovat’ a časovo zaradit'. Rámcovo patria do obdobia od druhej polovice 2. stor. do prvej tretiny 3. stor. Na základe uvedeného je pravdepodobné, že tažisko nálezov spadá až do severovského obdobia (Gabler 2012a, 124-126; 2012b, 422-435; Mees 2002, 323, 324, 329-332, 336, 337, 341-343, 346-348, 350).

Tabela 2. Trstené pri Hornáde, okr. Košice okolie. Prehlad terry sigillaty zo sídliskových objektov.

\begin{tabular}{|c|c|c|c|c|c|}
\hline Nálezový kontext & Dielňa & Typ nádoby & Majster & Datovanie & Kat. č. \\
\hline Objekt 6 & Rheinzabern & Drag. 37 & Belsus I & $180-220$ & 13 \\
\hline Objekt 13 & Westerndorf & Drag. 30 & Comitialis & koniec 2.-zač. 3. stor. & 23 \\
\hline \multirow{3}{*}{ Objekt 16} & Rheinzabern & Drag. 37 & $?$ & 2. pol. 2.-1. tret. 3. stor. & 17 \\
\hline & Rheinzabern & Drag. 37 & $?$ & 2. pol. 2.-1. tret. 3. stor. & 18 \\
\hline & Rheinzabern & Drag. 37 & $?$ & 2. pol. 2.-1. tret. 3. stor. & 21 \\
\hline \multirow{3}{*}{ Objekt 18} & Lezoux & Drag. 37 & $?$ & 2. pol. 2. stor. $(150-180)$ & 5 \\
\hline & $\begin{array}{l}\text { Rheinzabern/ } \\
\text { Westerndorf? }\end{array}$ & Drag. 37 & $?$ & 2. pol. 2.-1. tret. 3. stor. & 22 \\
\hline & Pfaffenhofen & Drag. 37 & Helenius & 2. tret. 3. stor. & 28 \\
\hline \multirow{3}{*}{ Objekt 23} & Rheinzabern & Drag. 37 & Verecundus I & $180 / 190-220 / 230$ & 16 \\
\hline & Rheinzabern & Drag. 37 & $?$ & 2. pol. 2.-1. tret. 3. stor. & 19 \\
\hline & Rheinzabern & Drag. 37 & ? & 2. pol. 2.-1. tret. 3. stor. & 20 \\
\hline
\end{tabular}

Z hladiska nálezového kontextu treba uviesț, že presnejšie datovatelné fragmenty pochádzajú z povrchovej vrstvy a sídliskových vrstiev (A a B), kým so sídliskovými objektami (16, 18 a 23) možno spájat iba rámcovo datovatel'né nálezy (tabela 1; 2; ku kontextu pozri nižšie). V prípade jedného fragmentu (3,5\%) nebolo možné jednoznačne určit či pochádza z Rheinzabernu, alebo Westerndorfu (kat. č. 22; tab. IV: 15).

Na území východného Slovenska boli výrobky z Rheinzabernu, v porovnaní s tovarom iných dielní, najviac rozšírené. Svedčia o tom nálezy z d’alších 15 nálezísk, vrátane dvoch pohrebísk (Kvakovce a Zemplín). Sú medzi nimi aj výrobky doložené v Trstenom pri Hornáde (t. j. sigillata z dielní Cerialis, Comitialis, B. F. Attoni, Reginus II, Primitivus I; Kuzmová 2014, 173).

\section{Výrobky z Westerndorfu (kat. č. 23-27; tab. II: 3-5)}

K výrobnému centru vo Westerndorfe bolo na základe výzdoby jednoznačne priradených pät zlomkov (18 \% všetkých nálezov) z reliéfne zdobených misiek (Drag. $30-1$ ks, Drag. $37-4$ ks). Z nich sa tri fragmenty spájajú s dielňou Comitialis (kat. č. 23-25; tab. II: 3, 4), dva z nich vyrobil Decminus,

\footnotetext{
4 Tento nález bol P. Jurečkom pôvodne určený ako výrobok z Lezoux z druhej polovice 2. stor. (Jurečko 1983, 304, 47: 4), čo však nová analýza nepotvrdila.
} 
pracujúci u Comitiala a sú datované na koniec 2.-začiatok 3. stor. ${ }^{5}$ Jeden nález pochádza z dielne Helenia z prvej tretiny 3. stor. (kat. č. 26; tab. II: 5). Uvedené fragmenty sa nachádzali v povrchovej vrstve a sídliskových vrstvách A a B, iba jeden z nich sa spája s objektom 13 (tabela 1; 2; ku kontextu pozri nižšie).

Na území východného Slovenska je tovar z Westerndorfu evidovaný na dalších 10 náleziskách, prevažne sídliskách domáceho obyvatel'stva (výnimkou je iba pohrebisko v Zemplíne). Na rozdiel od Trsteného pri Hornáde na nich celkovo prevládajú produkty Helenia, v jednom prípade sa vyskytol aj výrobok z dielne Onnio(rix), datovaný do záverečnej fázy westerndorfskej produkcie (Kuzmová 2014, 173).

Výrobky z Pfaffenhofenu (kat. č. 28; tab. II: 6; IV: 11)

Z tejto dielne pochádza iba jeden, reliéfne zdobený fragment (Drag. 37 - 3,5 \%) vyrobený Heleniom v prvej tretine 3. stor. Patrí spolu so sigillatou z dielne Helenia vo Westerndorfe, príp. aj súvekých majstrov pôsobiacich $\mathrm{v}$ Rheinzaberne, $\mathrm{k}$ najmladším nálezom terry sigillaty $\mathrm{z}$ tejto lokality. Našiel sa v objekte 18 (ku kontextu pozri nižšie).

V Trstenom pri Hornáde sa pri povrchovom zbere našiel ešte jeden fragment, ktorý bol následne určený ako výrobok z Pfaffenhofenu (Čaplovič/Gašaj/Olexa 1978, 66, obr. 35: 3; Kuzmová/Roth 1988, 114, obr. 26: 11). Na základe výzdobných prvkov pochádza zrejme tiež z dielne Helenia.

Z územia východného Slovenska sú výrobky z Pfaffenhofenu známe z dalších siedmich sídlisk domáceho obyvatelstva a z jedného pohrebiska (Zemplín). Okrem výrobkov Helenia sú medzi nimi doložené aj výrobky Dicana, hrnčiara pôsobiaceho v neskorej fáze tejto dielne (Kuzmová 2014, 173).

\section{NÁLEZOVÉ SÚVISLOSTI TERRY SIGILLATY}

Ako už bolo uvedené, autor výskumu P. Jurečko v roku 1983 čiastočne publikoval výsledky prvých dvoch výskumných sezón (Jurečko 1983, 277-389). Metodika výskumu spočívala v postupnom odkrývaní plochy po mechanických, asi $20 \mathrm{~cm}$ hrubých vrstvách. Podla nálezov z týchto vrstiev nachádzajúcich sa pod povrchovou vrstvou (hĺbka 0-30 cm) vyčlenil tri hlavné stratigrafické a chronologické sídliskové horizonty, ktoré označil ako: vrstva $\mathrm{A}$ - mladšia doba rímska (híbka $30-80 \mathrm{~cm}$ ); vrstva $\mathrm{B}$ - staršia doba rímska (híbka 80-120 cm); vrstva C - najstarší úsek staršej doby rímskej a vrstvy súvisiace s predchádzajúcim osídlením lokality (híbka 120-200 cm). Počas nasledujúceho výskumu sa odkryli dalšie archeologické štruktúry, z ktorých vyplynulo, že vývoj osídlenia lokality v dobe rímskej bol zložitejší a uvedené sídliskové horizonty možno akceptovat iba ako rámcové stratigrafické jednotky, bez jednoznačného chronologického zaradenia. Pri súčasnom, komplexnom spracovaní výsledkov výskumu sa zo stratigrafického hladiska zohladňuje P. Jurečkom vyčlenená vrstva A $(30-80 \mathrm{~cm})$ a vrstva B (80-200 $\mathrm{cm})$, ktorá zodpovedá pôvodným vrstvám B a C. Uvedené údaje sú určujúce aj pre nálezy terry sigillaty z týchto vrstiev. Celkovo ide o 17 zlomkov, čo prevyšuje počet nálezov z výplne identifikovaných sídliskových objektov (11 ks, pozri nižšie). Počet zlomkov z jednotlivých vrstiev je pritom vyrovnaný (tabela 1).

\section{Terra sigillata z vrstiev}

Z povrchovej vrstvy pochádza celkom pät nálezov z troch výrobných centier (Lezoux, Rheinzabern a Westerndorf). K najstarším a najpočetnejším (3 ks) patria výrobky Cinnama a Albucia z Lezoux, datované do druhej polovice 2. stor., presnejšie do obdobia markomanských vojen (kat. č. 1; 2; 4; tab. I: $1,2,4)$. Najmladším nálezom je výrobok Helenia z Westerndorfu z prvej tretiny 3. stor. (kat. č. 26; tab. II: 5), kým fragment z Rheinzabernu je iba rámcovo datovatelný do obdobia od druhej polovice 2., do prvej tretiny 3. stor. (kat. č. 8; tab. I: 5).

V sídliskovej vrstve A bolo evidovaných šest nálezov, presnejšie po dva zlomky z Lezoux, Rheinzabernu a Westerndorfu. Zo stredogalského výrobného centra bol bližšie určený iba jeden nález z obdobia markomanských vojen (Albucius?; kat. č. 3; 6; tab. I: 3), dva zlomky z Rheinzabernu pochádzajú z konca 2.-začiatku 3. stor. (kat. č. 10; 14; tab. I: 7, 11), a podobne aj d’alšie dva fragmenty z Westerndorfu, z ktorých jeden možno spájat’ s dielňou Comitialis - Decminus (kat. č. 25; 27; tab. II: 4).

5 Jeden z nich bol P. Jurečkom pôvodne určený ako výrobok z Lezoux z druhej polovice 2. stor. (Jurečko 1983, 304, 47: 5), nová analýza to však nepotvrdila. 
V sídliskovej vrstve B sa našlo taktiež šest’ zlomkov s prevahou rheinzabernskej terry sigillaty (4 ks), pričom výrobky z Lezoux a Westerndorfu sú tu zastúpené jedným exemplárom. Za najstarší z nich možno považovat nález z Lezoux z druhej polovice 2. stor., ktorý je jediným zástupcom hladkej terry sigillaty na skúmanej lokalite (Drag. 33; kat. č. 7). Ostatné nálezy zastúpené výrobkami viacerých majstrov z Rheinzabernu (kat. č. 9; 11; 12; 15; tab. I: 6, 8, 9, 12) a dielňou Comitialis - Decminus z Westerndorfu (kat. č. 24; tab. II: 3), spadajú prevažne na koniec 2. až začiatok 3. stor., t. j. do severovského obdobia.

Z uvedeného vyplýva, že terra sigillata z povrchovej a z nasledujúcich dvoch sídliskových vrstiev (A a B) je z typologického hladiska pomerne pestrá a jej chronologické zaradenie je značne široké. V každej z nich sú zastúpené dielne Lezoux, Rheinzabern a Westerndorf, ktorých výrobky možno časovo zaradit do obdobia od druhej polovice 2. do prvej tretiny 3. stor., t. j. do antoninovského/neskoroantoninovského až severovského obdobia.

\section{Terra sigillata z objektov}

Ďalšia skupina terry sigillaty zo sídliska v Trstenom pri Hornáde pochádza z piatich sídliskových objektov rôznych typov a rôznej funkcie. V porovnaní s nálezmi z vrstiev sú tu zastúpené nielen v nižšom počte, ale nižšia je aj ich typologická a chronologická výpovedná hodnota. Nálezové súvislosti týchto zlomkov sú zaznamenané vo výskumnej dokumentácii (Jurečko 1982b) a boli čiastočne aj publikované, ale ich interpretácia nie je vždy jednoznačná. Autor výskumu totiž uvádza, že vrchná čast’ sídliska bola z väčšej časti porušená hlbokou orbou a po odstránení povrchovej vrstvy bolo velmi tažké rozlíšit výplň mladších objektov od objektov zo staršieho horizontu (Jurečko 1983, 277-389). Išlo o súvislé vrstvy mazanice premiešanej s kamením, ktoré zrejme prislúchali k určitým objektom (objekt 16) alebo o ohniská a vrstvy neprepálenej mazanice, pod ktorými sa v niektorých prípadoch nachádzala kultúrna vrstva, pravdepodobne výplň príslušných objektov (objekt 23). Ďalšie nálezové celky sa na základe výplne dali jednoznačne identifikovat’ až v híbke $80 \mathrm{~cm}$ a určit ako zásobnicové či odpadové jamy (objekty 6 a 13) a kolové jamy. Z dvoch objektov odkrytých v superpozícii a interpretovaných ako obydlia (objekty 18 a 20) sa iba $v$ jednom našli zlomky terry sigillaty (objekt 18), ale vzhladom na uvedenú nálezovú situáciu bolo aj druhé obydlie (objekt 20) zahrnuté do tohto príspevku.

\section{Objekt 6}

Autor výskumu interpretoval tento objekt ako jednodielnu hrnčiarsku pec (Jurečko 1983, 285-287). $\mathrm{V}$ jeho popise je uvedené, že medzi predpecnou jamou a samotnou pecou bola zistená hlinená stena, v strede s náznakom (zvyškami) kanála, ako aj torzo hlineného roštu pece so štyrmi otvormi. Tieto konštrukčné prvky však neboli zdokumentované ani fotograficky ani kresbovo. Napriek tomu sa možno domnievat', že išlo skôr o superpozíciu dvoch sídliskových jám. V príslušnej výplni sa nachádzali zlomky jemnej stolovej keramiky przeworskej kultúry (tab. III: 1, 2), v ruke formovanej hrubej keramiky (tab. III: $4,5,7$ ) a jemnej, na kruhu vyrobenej keramiky (tab. III: 3, 6). Okrem nich sa tu našiel aj zlomok hornej časti nádoby s perforovanými stenami (tab. III: 8) a zlomok zásobnice s okružím. Súčastou výplne bolo aj niekol'ko zlomkov v ruke vyhotovených hrncovitých nádob zdobených plastickou výzdobou (tab. III: 9, 10), súvisiacich s pravekým osídlením lokality. Takéto typy nádob sú totiž známe napríklad z pohrebiska zo staršej doby železnej v Ždani a chronologicky patria do stupňov HC2/HD1, resp. do stupňa HD1 až na začiatok stupňa HD2 (Miroššayová 2015, 37, obr. 11).

Z tohto objektu pochádza jediný zlomok terry sigillaty z konca 2. až začiatku 3. stor. (Rheinzabern, Belsus I; kat. č. 13; tabela 2; tab. I: 10; III: 11). Jeho časové zaradenie čiastočne korešponduje s datovaním ostatného nálezového materiálu, na základe čoho bol objekt 6 rámcovo datovaný do stupňa B2/C1 doby rímskej.

\section{Objekt 13}

Ide o zásobnicovú jamu hruškovitého tvaru, ktorá obsahovala zlomky v ruke formovanej hrubej keramiky, pochádzajúce z ústia, tela a dna hrncovitých nádob, dalej drobné zlomky jemnej stolovej keramiky przeworskej kultúry z ústia a tela nádob, zrekonštruovatelnú hrncovitú nádobu sivej, na kruhu točenej keramiky, ako aj zlomky mazanice a zuholnatené semená šošovice kuchynskej. Objekt bol podla nálezového materiálu zaradený do staršej doby rímskej (Jurečko 1983, 283). Tomuto datovaniu však nezodpovedá chronologické určenie jediného zlomku terry sigillaty (Westerndorf, Comitialis; kat. č. 23; tabela 2), ktoré spadá na koniec 2. až začiatok 3. stor., s t’ažiskom v severovskom období. 


\section{Objekt 16}

Výplň tohto objektu, ktorú tvorila súvislá vrstva prepálenej mazanice nepravidelného tvaru, bola zachytená v híbke 40-80 cm. Počas tretej výskumnej sezóny lokality v roku 1982 sa zistilo jeho pokračovanie východným smerom $\mathrm{v}$ podobe dvoch pozdížnych zoskupení kamennej deštrukcie a kúskov prepálenej mazanice bližšie neurčeného tvaru. Podla autora výskumu išlo o deštrukciu polozemnice (Jurečko 1983, 285). Jej tvar ani výplň sa nedali jednoznačne oddelitł od príslušnej kultúrnej vrstvy. Nálezy v nej boli premiešané a pochádzali z híbky 60 až $80 \mathrm{~cm}$. Ide o zlomky hrubých, v ruke robených nádob bez výzdoby, zlomky jemnej na kruhu formovanej keramiky (tab. III: 12, 14, 16), z ktorých jeden má vhladzovanú a jeden kolkovanú výzdobu (tab. III: 17, 18), d’alej o dva zlomky jemnej stolovej keramiky przeworskej kultúry a fragmenty zásobníc s okružím (tab. III: 15). Vo výplni sa okrem nich našli aj zlomky železnej trosky, neidentifikovatelných železných predmetov a bronzová spona s podviazanou nôžkou (tab. III: 13).

Objekt bol podla uvedeného materiálu datovaný do mladšej doby rímskej (stupne C1-C2). Všetky tri zlomky terry sigillaty, ktoré sa v objekte našli mohli byt’ iba rámcovo zaradené do obdobia od druhej polovice 2. do prvej tretiny 3. stor. (Rheinzabern, kat. č. 17; 18; 21; tab. II: 2; III: 19-21; tabela 2), čo čiastočne zodpovedá chronologickému zaradeniu ostatných nálezov.

\section{Objekt 18}

Objekt s kolovou konštrukciou interpretovaný ako obydlie bol preskúmaný v roku 1982 a neskôr čiastočne publikovaný (Kol. AOVM 1984, 112-114). Podla zachovanej výskumnej dokumentácie bol v superpozícii s objektom 20. Začal sa črtat' až v híbke $100 \mathrm{~cm}$ a jeho obrys sa dal konkretizovat’ v híbke 115 $\mathrm{cm}$. V jeho hornej časti sa nachádzala vrstva neprepálenej žltej hliny premiešanej s kameňmi, ktorá pokračovala západným smerom mimo pôdorysu objektu. Výplň pozostávala z tmavohnedej hliny a obsahovala početné nálezy. Na jeho dne, v hlibke $145 \mathrm{~cm}$, sa nachádzala udupaná hlinená dlážka.

V nálezovom materiáli prevládajú zlomky v ruke formovanej hrubej keramiky pochádzajúce $\mathrm{z}$ hrncovitých a miskovitých nádob výraznej esovitej profilácie a zlomky zo zásobníc zdobené rytými vlnovkami. V súbore sa nachádzajú aj časti dvoch nádob, ku ktorým na základe typu a rozmiestnenia výzdoby možno nájst’ analógie v kvádskej keramike (Varsik 2011, 85, 86, obr. 45). Ide o hornú čast’ hrncovitej nádoby, zdobenej na ústí a na rozhraní hrdla a tela pásom šikmých zárezov (tab. IV: 6) a o čast̉ v ruke vyrobenej misky z jemnej hliny, ktorá má na maximálnej vydutine obežný prstenec s podobnou výzdobou ako v predchádzajúcom prípade a nad ním sú vertikálne žliabky (tab. IV: 7). Niekol'ko zlomkov v ruke formovanej keramiky má plastickú výzdobu akú poznáme na dáckej keramike (tab. IV: 8). Ďalej ide o zlomky jemnej stolovej keramiky przeworskej kultúry, ktoré pochádzajú z miskovitých a vázovitých nádob (tab. IV: 1, 2). Vo väčšine prípadov majú čierny leštený povrch, pričom niekol'ko zlomkov je svetlohnedej farby, s lešteným povrchom, ale bez tuhovania. V jednom prípade je zlomok z ústia nádoby čiernej farby zdobený rytou výzdobou (tab. IV: 1). V objekte boli aj fragmenty nádob jemnej, na kruhu formovanej keramiky svetlosivej a čiernej farby, bez výzdoby (tab. IV: 9). Jeden z nich má drsný povrch a výrazne profilované ústie (tab. IV: 10). K rímskoprovinciálnym výrobkom patrí zlomok panónskej jemnej sivej (tab. IV: 14) a tehlovej keramiky (tab. IV: 13; pozri tiež Kuzmová/Rákoš 2016, 168, 169). K zatial' neidentifikovaným patrí zlomok z ústia nádoby so zachovanou častou kolienkového uška (tab. IV: 5). Vo výplni tohto objektu sa našla aj bronzová doštičková spona zdobená emailom (tab. IV: 3; súhrnne pozri Kuzmová/Rákoš 2016, 168, 169) a bronzová spona s hrotitou nôžkou VI. Almgrenovej skupiny (tab. IV: 4). Ked’že sa objekt nachádzal v superpozícii s objektom 20, mohlo dôjst’ k čiastočnému zmiešaniu ich výplní. Na základe uvedeného nálezového materiálu možno objekt 18 rámcovo datovat do stupňov B2/C1-C2.

Z tohto objektu pochádzajú tri zlomky terry sigillaty so širokým chronologickým rozpätím, ktorých pôvod sa spája s tromi, príp. štyrmi, výrobnými centrami (tabela 2). Z nich najstarším je zrejme stredogalský výrobok z druhej polovice 2. stor. (kat. č. 5; tab. IV: 12) a najmladším výrobok z Pfaffenhofenu, $\mathrm{z}$ dielne Helenia, z druhej tretiny 3. stor. (kat. č. 28; tab. II: 6; IV: 11). Pri tretom zlomku nemožno jednoznačne určit, či pochádza z Rheinzabernu alebo Westerndorfu, preto je aj jeho datovanie od druhej polovice 2. až do prvej tretiny 3. stor. iba rámcové (kat. č. 22; tab. IV: 15). Na základe uvedeného spadá datovanie nálezov terry sigillaty do vyššie uvedeného časového rámca objektu.

\section{Objekt 20}

Napriek tomu, že objekt neobsahoval terru sigillatu, dôvodom jeho zaradenia do príspevku je jeho čiastočná subpozícia s objektom 18. Ide o obytný objekt kolovej konštrukcie s nepravidelným pôdorysom, ktorého prevažná čast’ sa nachádzala južne od objektu 18 (tab. IV). Nad objektom 20 sa v hlbke $120 \mathrm{~cm}$ nachádzala $20 \mathrm{~cm}$ hrubá súvislá vrstva neprepálenej mazanice a pod ňou rovnako hrubá vrstva uhlíkov 
a zuholnateného, resp. prepáleného dreva. Na dne objektu bola $5 \mathrm{~cm}$ hrubá vrstva výraznej hnedej zeminy s početnými nálezmi. Udupaná hlinená dlážka, ktorá pokračovala aj pod dlážku mladšieho objektu 18, sa nachádzala v híbke $150 \mathrm{~cm}$ (Jurečko 1982b).

Výplň objektu 20 obsahovala zlomky hrncovitých a miskovitých nádob v ruke formovanej hrubej keramiky bez výzdoby (tab. V: 4-6), iba jeden zlomok z okraja väšejej hrncovitej nádoby má okraj pretláčaný prstami (tab. V: 1). Ďalší zlomok je zdobený plastickým výčnelkom (tab. V: 14) aké poznáme na dáckej keramike. Totožná plastická výzdoba je napríklad aj na zlomkoch zo sídliska Otałęzy v Polsku, kde sa spoločne s dáckou keramikou vyskytuje aj jemná stolová keramika przeworskej kultúry (Podgórska-Czopek 1999, 138, 139). S dáckym etnikom pravdepodobne súvisí aj jediný okrajový zlomok na kruhu točenej keramiky pochádzajúci z objektu 20 (tab. V: 11). Okrem nich sa tu našli aj zlomky jemnej stolovej keramiky przeworskej kultúry (tab. V: 7-10, 12, 13) s čiernym tuhovaným povrchom. Provinciálnu keramiku tu zastupujú zlomky panónskej pásikovej a plošne malovanej keramiky (tab. V: 2). Medzi nálezmi datovanými do doby rímskej sa nachádza aj hlinený praslen a kostená ihlica (tab. V: 16). V objekte sa sekundárne vyskytli aj zlomky keramiky z doby halštatskej, zlomok z ústia laténskej situly (tab. V: 15) a zlomok zdobený rytou výzdobou z mladšej doby bronzovej (tab. V: 3). Nálezový materiál $\mathrm{z}$ doby rímskej datuje objekt do stupňa B2/C1.

\section{Objekt 23}

Vo vrchnej časti mohutnej kultúrnej vrstvy, zachytenej v híbke 40 až $100 \mathrm{~cm}$, sa nachádzala súvislá vrstva mazanice, ktorú autor výskumu interpretoval ako zvyšky zrútených stien obydlia (Jurečko 1982b). Výplň pod ňou, tvorená popolovitou šedou hlinou, obsahovala v hĺbke 80 až $100 \mathrm{~cm}$ početné nálezy. Patria k nim zlomky v ruke formovanej hrubej keramiky (tab. V: 18-21, 25), zdobené pretláčaním prstami, horizontálnym radom vpichov na maximálnom vydutí nádob a plastickou výzdobou. Jeden zlomok je zdobený barbotinom (tab. V: 21). Ďalej sú to zlomky jemnej stolovej keramiky przeworskej kultúry (tab. V: 22-24), početné zlomky z nádob jemnej, na kruhu formovanej keramiky (tab. V: 28-31) a zlomky z vel'kých zásobníc s okružím. Rímskoprovinciálnu keramiku zastupuje zlomok z pohára s prehýbanými stenami (tab. V: 27) a fragmenty panónskej tehlovej (tab. V: 26) i celoplošne malovanej keramiky. Z ostatných nálezov datovaných do doby rímskej možno uviest' pät celých a dva zlomky praslenov, časti kamenných brúsikov, železný krúžok a fragmenty kosteného hrebeňa (tab. V: 17). Ide o trojvrstvový hrebeň typu Thomas III, ktorý mal polkruhovitú rukovät ukončenú obdížnikovitým rozšírením, na ktorom sa nachádza rytý ornament. Dva hrebene tohto typu sa našli napríklad v Ostrovanoch (Lamiová-Schmiedlová/Tomášová 1999, 104). S. Thomas (1960, 104-114) datuje tento typ hrebeňov do 4., resp. na začiatok 5. stor. V tomto kontexte sa sekundárne vyskytlo aj niekol'ko fragmentov keramiky z doby halštatskej. Podla uvedeného nálezového materiálu z doby rímskej možno objekt datovał do mladšej doby rímskej až na začiatok doby stahovania národov (stupne C3-D).

$\mathrm{V}$ objekte 23 sa našli aj tri fragmenty rheinzabernskej terry sigillaty (tabela 2). Z nich bol bližšie určitelný iba jeden ako produkt majstra Verecundus I z neskoroantoninovského až severovského obdobia (kat. č. 16; tab. II: 1). Ďalšie dva boli iba rámcovo datovatelné do obdobia od druhej polovice 2. do prvej tretiny 3. stor. (kat. č. 19; 20). V tomto prípade možno konštatovat', že medzi datovaním terry sigillaty a datovaním ostatných nálezov z tohto objektu je značný časový rozdiel.

\section{ZHRNUTIE}

Z analýzy súboru terry sigillaty zo sídliska przeworskej kultúry v Trstenom pri Hornáde vyplynulo, že pozostáva z výrobkov štyroch produkčných centier (Lezoux, Rheinzabern, Westerndorf a Pfaffenhofen) situovaných v západorímskych provinciách. Do tejto časti barbarika sa dostali najskôr prostredníctvom Panónie. Takmer výlučne ide o zlomky reliéfne zdobených misiek (Drag. 37, príp. 30), výnimkou je iba jeden nález hladkej terry sigillaty vyrobený v strednej Galii (Drag. 33).

K najvčasnejším nálezom skúmaného súboru patrí terra sigillata zo strednej Galie $(7$ ks, 25 \% všetkých nálezov), datovaná do druhej polovice 2 stor. Osobitný význam majú výrobky Cinnama a Albucia z Lezoux, doložené aj v panónskych zánikových horizontoch spájaných s markomanskými vojnami, ktorých záver určuje hornú hranicu distribúcie stredogalských produktov do tejto provincie (rok 180). V najväčšom počte sú na nálezisku doložené výrobky z Rheinzabernu (14 ks - 50 \%). Pri viac ako polovici z nich $(9 \mathrm{ks})$ boli určení aj výrobcovia - hrnčiarski majstri. Napriek tomu je datovanie väčšiny z nich 
pomerne široké. Niektoré sú síce datovatelné aj do obdobia markomanských vojen, ale prevaha nálezov pochádza zrejme zo severovského obdobia. K výrobnému centru vo Westerndorfe bolo na základe výzdoby jednoznačne priradených pät zlomkov (18\%), rámcovo datovaných do severovského obdobia. Z dvoch identifikovaných majstrov tu prevládajú výrobky Comitiala, z konca 2. až zo začiatku 3. stor., nad výrobkami Helenia z prvej tretiny 3. stor. K najmladším produktom patrí aj jediný reliéfne zdobený fragment (3,5\%) vyrobený Heleniom v dielni Pfaffenhofen v prvej tretine 3. stor.

Z hladiska nálezových súvislostí sa terra sigillata v Trstenom pri Hornáde spája s tromi stratigraficky vyčlenenými vrstvami a s výplňou piatich sídliskových objektov. Nálezy z vrstiev (17 ks) prevyšujú svojím počtom nálezy z objektov $(11 \mathrm{ks})$. Terra sigillata z povrchovej a z nasledujúcich dvoch sídliskových vrstiev (A a B) je typologicky pomerne pestrá, pričom aj jej chronologické zaradenie je značne široké. V každej z uvedených vrstiev sú zastúpené výrobky z Lezoux, Rheinzabernu a Westerndorfu, rámcovo datované do obdobia od druhej polovice 2. do prvej tretiny 3. stor., t. j. do antoninovského/neskoroantoninovského až severovského obdobia.

Druhá skupina nálezov terry sigillaty súvisí so sídliskovými objektami rôznej funkcie, rôzneho typu a časového zaradenia, od staršej až do neskorej doby rímskej, príp. až na začiatok doby stahovania národov. Do staršej doby rímskej bol na základe domácej keramiky rámcovo datovaný objekt 13 - zásobnicová jama hruškovitého tvaru. Tomuto datovaniu však nezodpovedá chronologické určenie jediného zlomku terry sigillaty z jeho výplne (Westerndorf, Comitialis), ktoré spadá na koniec 2 . až začiatok 3. stor., s tažiskom v severovskom období.

Do stupňov B2/C1 a B2/C1-C2 doby rímskej boli rámcovo zaradené dva objekty (6 a 18). Z hladiska funkcie bol objekt 6 pôvodne publikovaný ako jednodielna hrnčiarska pec, podla novej analýzy ide skôr o superpozíciu dvoch sídliskových jám. Z príslušnej výplne pochádza jediný zlomok terry sigillaty z konca 2. až začiatku 3. stor. (Rheinzabern, Belsus I). Jeho chronologické určenie čiastočne korešponduje s datovaním ostatného nálezového materiálu (výlučne domácej keramiky), na základe ktorého bol objekt rámcovo zaradený do stupňa B2/C1 doby rímskej. Objekt $18 \mathrm{~s}$ kolovou konštrukciou je interpretovaný ako obydlie. Pochádzajú z neho tri nálezy terry sigillaty, ktorých pôvod sa spája s tromi, príp. štyrmi, výrobnými centrami (stredná Galia/Lezoux, Rheinzabern alebo Westerndorf a Pfaffenhofen). Rámcové datovanie týchto nálezov do druhej polovice 2. až prvej tretiny 3. stor. čiastočne zodpovedá časovému zaradeniu objektu do stupňov B2/C1-C2 doby rímskejna základe ostatných nálezov. Patria k nim prevažne zlomky keramiky przeworskej kultúry, ale aj fragmenty s výzdobnými prvkami známymi z kvádskeho i dáckeho prostredia, a tiež panónskej keramiky. Z kovových predmetov sú určujúce dve bronzové spony - emailová doštičková spona a spona s hrotitou nôžkou VI. Almgrenovej skupiny. Nemožno opomenút, že objekt 18 sa nachádzal v superpozícii s objektom 20, pokladaným tiež za obydlie zo stupňov B2/C1 doby rímskej, ktorý síce neobsahoval terru sigillatu, ale jeho keramický nálezový materiál je podobného rázu, čo nevylučuje ani čiastočné zmiešanie ich výplní.

Do stupňov C1-C2 doby rímskej bol datovaný objekt 16 interpretovaný ako obydlie - polozemnica. $S$ jeho výplňou sa spájajú tri zlomky terry sigillaty z Rheinzabernu, ktoré mohli byte iba rámcovo zaradené do obdobia od druhej polovice 2. do prvej tretiny 3. stor. Ich datovanie je čiastočne $\mathrm{v}$ súlade s datovaním objektu do mladšej doby rímskej (stupne C1-C2), na základe sprievodných nálezov. Okrem domácej keramiky k nim patrí aj bronzová spona s podviazanou nôžkou.

Najmladšiu fázu sídliska (stupne C3-D doby rímskej) zastupuje objekt 23, pravdepodobne obydlie, $\mathrm{v}$ ktorom sa našli tri fragmenty rheinzabernskej terry sigillaty. Z nich bol bližšie určitelný iba jeden ako produkt majstra Verecundus I z neskoroantoninovského až severovského obdobia. Ďalšie dva boli iba rámcovo datovatelné do obdobia od druhej polovice 2. do prvej tretiny 3. stor. V tomto prípade možno konštatovat', že medzi datovaním terry sigillaty a ostatných nálezov z objektu je značný časový rozdiel, ked’̌̌e spadajú do neskorej doby rímskej až na začiatok doby stahovania národov (stupne C3-D). Patria k nim najmä zlomky domácej a rímskoprovinciálnej keramiky a fragmenty kosteného hrebeňa typu Thomas III.

Terra sigillata zo sídliska v Trstenom pri Hornáde predstavuje najpočetnejší súbor tejto keramiky z územia dnešného východného Slovenska $(28 \mathrm{ks})$. Na základe porovnania nálezov z jeho areálu a zo súvekých lokalít evidovaných $\mathrm{v}$ uvedenej časti barbarika možno poukázat’ na isté špecifiká. Z hladiska pôvodu nálezov v oboch prípadoch výrazne prevládajú výrobky z Rheinzabernu, pričom ich podiel je v Trstenom pri Hornáde o niečo vyšší (50:46\%). V prípade terry sigillaty z Westerndorfu je percentuálne zastúpenie takmer vyrovnané (18: 20 \%). Väčšie rozdiely sa ukázali pri výrobkoch z Lezoux a z Pfaffenhofenu. Kým podiel terry sigillaty z Lezoux je na skúmanom nálezisku značne vyšší ako na ostatnom území východného Slovenska (25: 6 \%), v prípade výrobkov z Pfaffenhofenu je to naopak (3,5: 20 \%). 
Tento jav možno v prvom rade spájał’ s intenzitou kontaktov medzi Rimanmi a domorodým obyvatel'stvom a osobitostami výmenno-obchodných a iných vztahov v počiatočnom a záverečnom období prílevu týchto hrnčiarskych výrobkov, t. j. v tretej štvrtine 2. stor. (Lezoux) a v druhej štvrtine 3. stor. (Pfaffenhofen). Napriek uvedenému, obdobie výskytu terry sigillaty v Trstenom pri Hornáde i na príslušnom území východného Slovenska je rámcovo identické, spadá do druhej polovice 2. až prvej polovice 3. stor., pričom tažisko spočíva v severovskom období.

\section{KATALÓG TERRY SIGILLATY}

\section{Stredná Galia, Lezoux}

1. Inv. č. A 5582; povrchová vrstva, híbka 0-30 cm (tab. I: 1).

Črep z tela misky typu Drag. 37. Farba hnedočervená, povrch matne lesklý. Metopy členené perlovcom (Rogers 1974, A2), na spoji hladký prstenec. V metope vlavo dvojitý hladký kruh, astragal (CGP, obr. 47: 40), v metope vpravo bradatá hlava dolava (O. 1214).

Lezoux, Cinnamus.

Antoninovské obdobie (145-170/178).

2. Inv. č. A 5474; povrchová vrstva (tab. I: 2).

Črep zo spodnej časti misky typu Drag. 37. Farba hnedočervená, povrch lesklý. Čast' listového kalicha (CGP, tab. 47: 21), zvislý perlovec (Rogers 1974, A2) dole ukončený krúžkom, hladký prstenec (CGP, tab. 47: 11). Reliéf je ukončený vodorovnou plastickou líniou.

Lezoux, Cinnamus (?).

Antoninovské obdobie (145-170/178).

3. Inv. č. A 5673; vrstva A, híbka 30-80 cm (tab. I: 3).

Črep z tela misky typu Drag. 37. Farba červená, povrch matne lesklý. Vajcovec (Rogers 1974, B 107?) na vodorovnom perlovci (Rogers 1974, A36). Sediaci Jupiter? (O. 3).

Lezoux, Albucius (?).

Antoninovské obdobie (r. 150-180).

4. Inv. č. A 5664-b; povrchová vrstva (tab. I: 4).

Črep z misky typu Drag. 37. Farba hnedočervená, povrch matne lesklý. Vajcovec (Rogers 1974, B 107?) na vodorovnom perlovci (Rogers 1974, A 36?). Vták so zdvihnutými krídlami dolava (O. 2324).

Lezoux, Albucius (?).

Antoninovské obdobie (150-180).

5. Inv. č. A 5551-a; objekt 18, vrstva B, híbka 80-145 cm (tab. IV: 12).

Okrajový črep z misky typu Drag. 37. Farba hnedočervená, povrch matne lesklý.

Stredná Galia.

Antoninovské obdobie (150-180).

6. Inv. č. A 5114; vrstva A.

Okrajový črep z misky typu Drag. 30, 37 (?). Farba červenohnedá, povrch matne lesklý, mierne olúpaný.

Stredná Galia.

Antoninovské obdobie (150-180).

Publ.: Jurečko 1983, 291, obr. 40: 3; Kuzmová/Roth 1988, 113.

7. Inv. č. A 5146; vrstva B, híbka 80-100 cm.

Okrajový črep z misky typu Drag. 33. Farba červenohnedá, mierne flakatá po druhotnom prepálení, povrch lesklý. Stredná Galia.

Antoninovské obdobie (150-180).

Publ.: Jurečko 1983, 304, obr. 47: 6; Kuzmová/Roth 1988, 113.

\section{Rheinzabern}

8. Inv. č. A 5344; povrchová vrstva (tab. I: 5).

Črep z misky typu Drag. 37. Farba hnedočervená, povrch matne lesklý, z vel'kej časti odlúpený. V zdobenom kruhu (Ri-Fi K 48) Triton alebo Scylla (Ri-Fi M 104).

Rheinzabern, Janu(arius) I, Cerialis, I, III, V, Comitialis I, II.

Antoninovské až severovské obdobie (druhá polovica 2.- prvá tretina 3. stor.). 
9. Inv. č. A 5450; vrstva B, híbka 120-130 cm (tab. I: 6).

Črep z tela misky typu Drag. 37. Farba červená, povrch matne lesklý, mierne olúpaný. Bojovník s kopijou a mečom (Ri-Fi M 181) medzi dvoma dvojitými hladkými kruhmi (Ri-Fi K 19). Reliéf je ukončený plastickou líniou.

Rheinzabern, Cobnertus III, Attilus, Primitivus I.

Neskoroantoninovské až severovské obdobie (160-220/230).

Publ.: pôvodne P. Jurečkom ako výrobok z Lezoux z druhej polovice 2. stor. (Jurečko 1983), čo však novšia analýza nepotvrdila.

10. Inv. č. A 5099; vrstva A, híbka 70-80 cm (tab. I: 7).

Črep z tela misky typu Drag. 37. Farba červenohnedá, povrch matne lesklý. Vajcovec (Ri-Fi E 1). Vpravo amor s palicou p. (Ri-Fi M 144), vlavo pygmej s krátkou zbraňou (Ri-Fi M 151).

Rheinzabern, Cerialis I, Comitialis I, B. F. Attoni.

Neskoroantoninovské až severovské obdobie (180-220/230).

Publ.: Jurečko 1983, 304, obr. 47: 8; Kuzmová/Roth 1988, 113, obr. $26: 8$.

11. Inv. č. A 5448; vrstva B, híbka 120-130 cm (tab. I: 8).

Črep z tela misky typu Drag. 37. Farba červená, povrch matne lesklý. Vajcovec (Ri-Fi E 1). Amor s palicou dol’ava (Ri-Fi M142), bradatá hlava dolava (Ri-Fi M 9) na opačne orientovanom podstavci (Ri-Fi O 13), okrajová ozdoba z dvojitých lístkov (Ri-Fi R 36).

Rheinzabern, Cerialis I, Belsus I.

Neskoroantoninovské až severovské obdobie (180-220).

12. Inv. č. A 5451; vrstva B, híbka 120-130 cm (tab. I: 9).

Črep z tela misky typu Drag. 37. Farba hnedočervená, povrch matne lesklý, sčasti olúpaný. Vajcovec (Ri-Fi E 1). Pygmej s mečom a štítom (Ri-Fi M 147).

Rheinzabern, Cerialis I, V, B. F. Attoni.

Neskoroantoninovské až severovské obdobie (180-220/230?).

13. Inv. č. A 5201; objekt 6, vrstva B (tab. I: 10; III: 11).

Črep zo spodnej časti misky typu Drag. 37. Farba červenohnedá, povrch matne lesklý, mierne olúpaný. Sediaci zajac dolava (Ri-Fi T 163), pod ním hladký prstenec s ružicou (Ri-Fi O 52 a). Reliéf je ukončený okrajovou výzdobou z dvojitých lístkov dol'ava (Ri-Fi R36).

Rheinzabern, Belsus I.

Neskoroantoninovské až severovské obdobie (180-220).

Publ.: Jurečko 1983, 304, obr. 55: 2; Kuzmová/Roth 1988, 114, obr. 26 : 9.

14. Inv. č. A 5382-a; vrstva A, híbka 50-70 cm (tab. I: 11).

Črep z tela misky typu Drag. 37. Farba hnedočervená, povrch matne lesklý. Viktória s palmou a vencom (Ri-Fi M 32), postava so zvieracou maskou (Ri-Fi M 109), hráč na flautu (Ri-Fi M 166).

Rheinzabern, Atto, Reginus II (?).

Severovské obdobie (190/200-230).

15. Inv. č. A 5547; vrstva B, híbka 80-120 cm (tab. I: 12).

Črep z tela misky typu Drag. 37. Farba červená, povrch matne lesklý. Vajcovec (Ri-Fi E 59). Pripútaná postava? (Ri-Fi M 232?).

Rheinzabern, Augustinus III.

Severovské obdobie (koniec 2. stor.).

16. Inv. č. A 5621-a; objekt 23, híbka 80-100 cm (tab. II: 1).

Črep z tela misky typu Drag. 37. Farba hnedočervená, povrch matne lesklý, mierne olúpaný. Dva dvojité hladké kruhy (Ri-Fi K 16), medzi nimi zvislý perlovec (Ri-Fi O 260), v pravom kruhu tri šikmé a tri zvislé paralelné perlovce uvedeného typu, dvojitý list (Ri-Fi P 142a).

Rheinzabern, Verecundus I.

Severovské obdobie (180/190-220/230).

17. Inv. č. A 5515-a; objekt 16, vrstva A, híbka 30-80 cm (tab. III: 19).

Okrajový črep z misky typu Drag. 37. Farba svetločervená, povrch matne lesklý, so stopami po sekundárnom prepálení. Neurčitel’ný vajcovec (podla vnútorného povrchu a zlomku vajcovca vykazuje istú podobnost’ s kat. č. 19).

Rheinzabern.

Antoninovské až severovské obdobie (druhá polovica 2.-prvá tretina 3. stor.).

18. Inv. č. A 5515-b; objekt 16, vrstva A, híbka 30-80 cm (tab. III: 21).

Okrajový črep z misky typu Drag. 37. Farba hnedočervená, povrch matne lesklý, zvonku odlúpený.

Rheinzabern.

Antoninovské až severovské obdobie (druhá polovica 2.-prvá tretina 3. stor.). 
19. Inv. č. A 5621-b; objekt 23, híbka 80-100 cm.

Okrajový črep z misky typu Drag. 37. Farba svetločervená, povrch matne lesklý, so stopami po sekundárnom prepálení. Neurčitelný vajcovec (podla vnútorného povrchu a zlomku vajcovca vykazuje podobnost’ s kat. č. 17).

Rheinzabern.

Antoninovské až severovské obdobie (druhá polovica 2.-prvá tretina 3. stor.).

20. Inv. č. A 5621-c; objekt 23, híbka 80-100 cm.

Črep zo spodnej časti misky typu Drag. 37. Farba červená, povrch matne lesklý.

Rheinzabern.

Antoninovské až severovské obdobie (druhá polovica 2.-prvá tretina 3. stor.).

21. Inv. č. A 5515-c; objekt 16, vrstva A, híbka 30-80 cm (tab. II: 2; III: 20).

Črep z tela pohára typu Déch. 72 (?). Farba červenohnedá, povrch matne lesklý mierne olúpaný. Barbotinová výzdoba v podobe brečtanového lístka na stonke.

Rheinzabern.

Antoninovské až severovské obdobie (druhá polovica 2.-prvá tretina 3. stor.).

22. Inv. č. A 5551-b; objekt 18, vrstva B, híbka 80-145 cm (tab. IV: 15).

Čast’ prstencovej nôžky z misky typu Drag. 37. Farba červenohnedá, povrch matne lesklý, sčasti ošúchaný.

Rheinzabern/Westerndorf (?).

Antoninovské až severovské obdobie (druhá polovica 2.-prvá tretina 3. stor.).

\section{Westerndorf}

23. Inv. č. A 5327; objekt 13, híbka 50-70 cm.

Črep zo spodnej časti misky typu Drag. 30 s odlomenou prstencovou nôžkou, matne lesklý povrch, olúpaný. Malý pes l.' (Kellner 1981, 39; Kiss 1946-1948, tab. 4: 37).

Westerndorf, Comitialis.

Severovské obdobie (koniec 2.-začiatok 3. stor.).

Publ.: Jurečko 1983, 301, obr. 42: 5; Kuzmová/Roth 1988, 114, obr. 26: 10.

24. Inv. č. A 5449; vrstva B, híbka 120-130 cm (tab. II: 3).

Črep z tela misky typu Drag. 37. Farba červená, povrch matne lesklý. Vajcovec (Kellner 1981, E2; Kiss 1946-1948, tab. 4: 4), vták doprava (Kellner 1981, 41; Kiss 1946-1948, tab. 4: 38).

Westerndorf, Comitialis (Decminus).

Severovské obdobie (koniec 2.-začiatok 3. stor.).

Publ.: pôvodne P. Jurečko ako výrobok z Lezoux z druhej polovice 2. stor. (Jurečko 1983, 304, tab. 47: 5), čo však novšia analýza nepotvrdila.

25. Inv. č. A 5495; vrstva A, híbka 60-80 cm (tab. II: 4).

Črep z tela misky typu Drag. 37. Farba červená, povrch matne lesklý. Vajcovec (Kellner 1981, E2; Kiss 1946-1948, tab. 4: 4), dvojitý hladký kruh (Kellner 1981, 67; Kiss 1946-1948, tab. 4: 57).

Westerndorf, Comitialis (Decminus).

Severovské obdobie (koniec 2.-začiatok 3. stor.).

26. Inv. č. A 5664-a; povrchová vrstva (tab. II: 5).

Črep z misky typu Drag. 37. Farba hnedočervená, povrch matne lesklý, sčasti ošúchaný. Dva vodorovné rady na seba nadväzujúcich členených polkruhov (Gabler/Kellner 1994, 151; Kiss 1946-1948, tab. 6: 80), další rad opačne orientovaný. Medzi hornými polkruhmi vodorovne orientovaný astragal (Gabler/Kellner 1994, 154; Kiss 1946-1948, tab. 6: 62), pod nimi dva prekrížené astragaly uvedeného typu.

Westerndorf, Helenius.

Severovské obdobie (prvá tretina 3. stor.).

27. Inv. č. A 5382-b; vrstva A, híbka 50-70 cm.

Dno z misky typu Drag. 37 s odlomenou prstencovou nôžkou. Farba červená, povrch matne lesklý, ošúchaný.

Westerndorf (?).

Severovské obdobie (?).

\section{Pfaffenhofen}

28. Inv. č. A 5551-c; objekt 18, vrstva B, híbka 80-145 cm (tab. II: 6, IV: 11).

Črep z tela misky typu Drag. 37. Farba tehlovočervená, povrch matne lesklý. V dvojitom hladkom kruhu (Pf. 13) vták vlavo (Pf. 8), členené lišty? (Pf. 32).

Pfaffenhofen, Helenius.

Severovské obdobie (druhá tretina 3. stor.). 

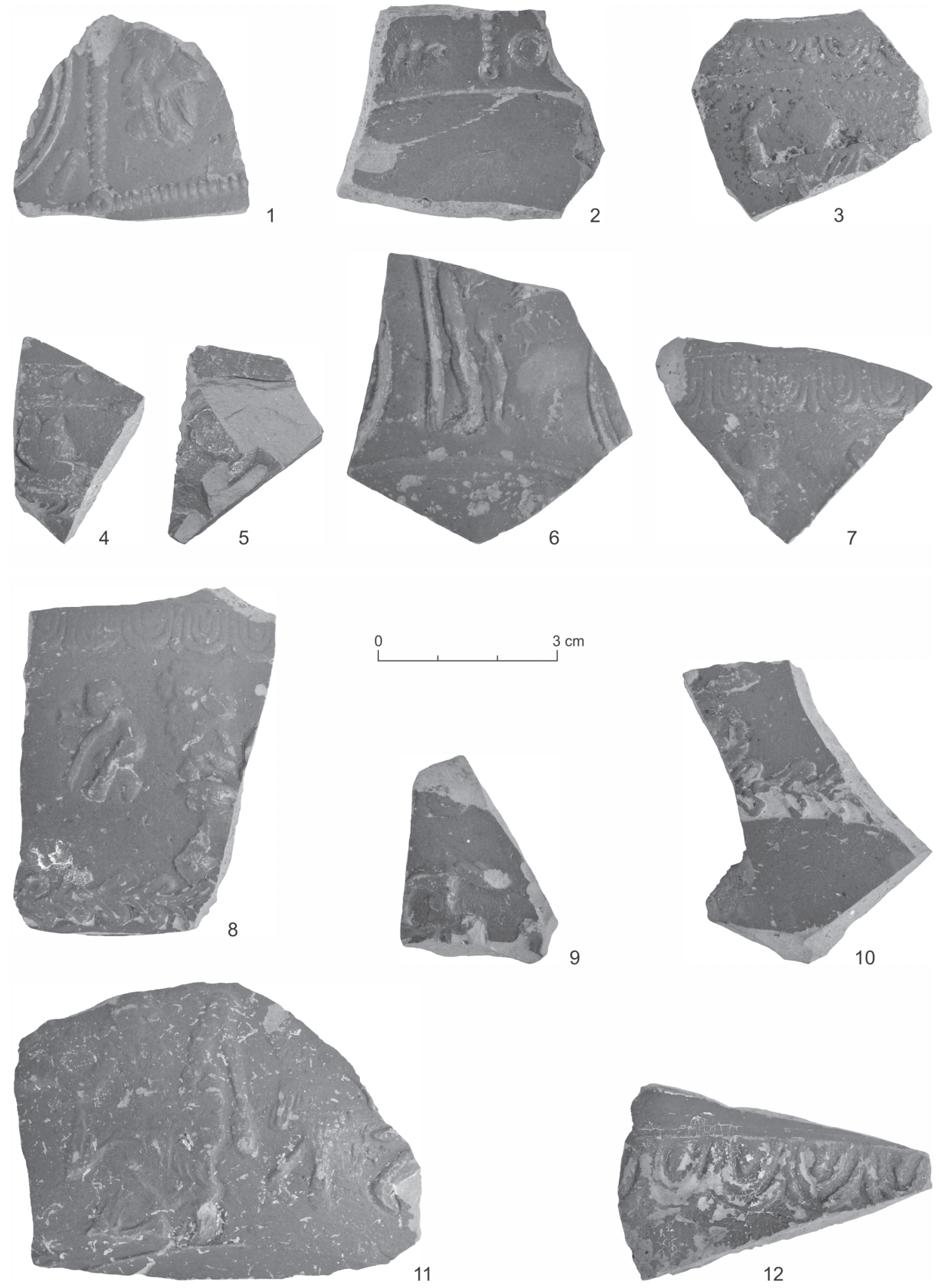

11

Tab. I. Trstené pri Hornáde, okr. Košice okolie. Výber nálezov terry sigillaty. 1-4 - stredná Galia, Lezoux; 5-12 - Rheinzabern. 


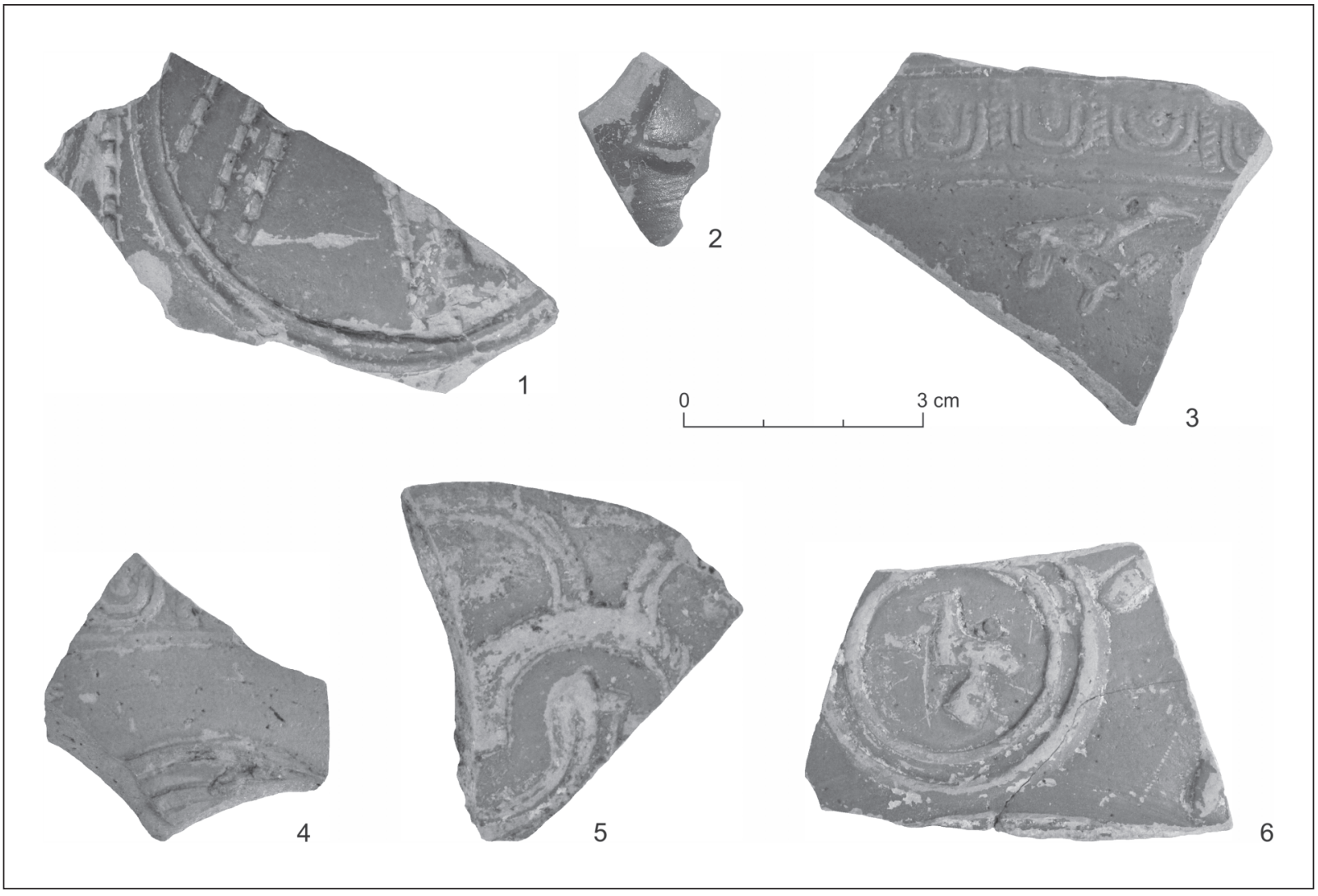

Tab. II. Trstené pri Hornáde, okr. Košice okolie. Výber nálezov terry sigillaty. 1-2 - Rheinzabern; 3-5 - Westerndorf; 6 - Pfaffenhofen. 

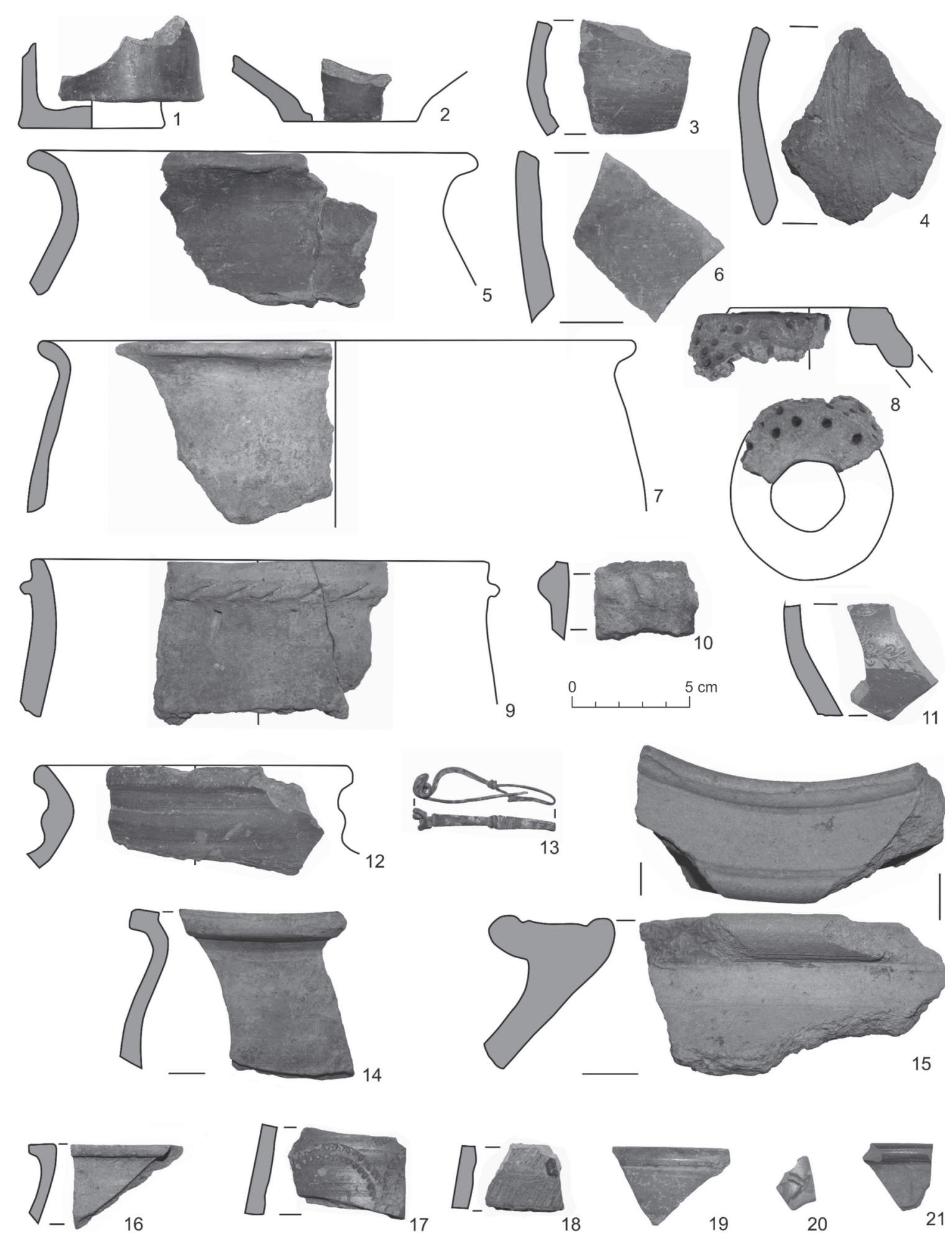
TERRA SIGILLATA V KONTEXTE SÍDLISKA PRZEWORSKEJ KULTÚRY V TRSTENOM PRI HORNÁDE

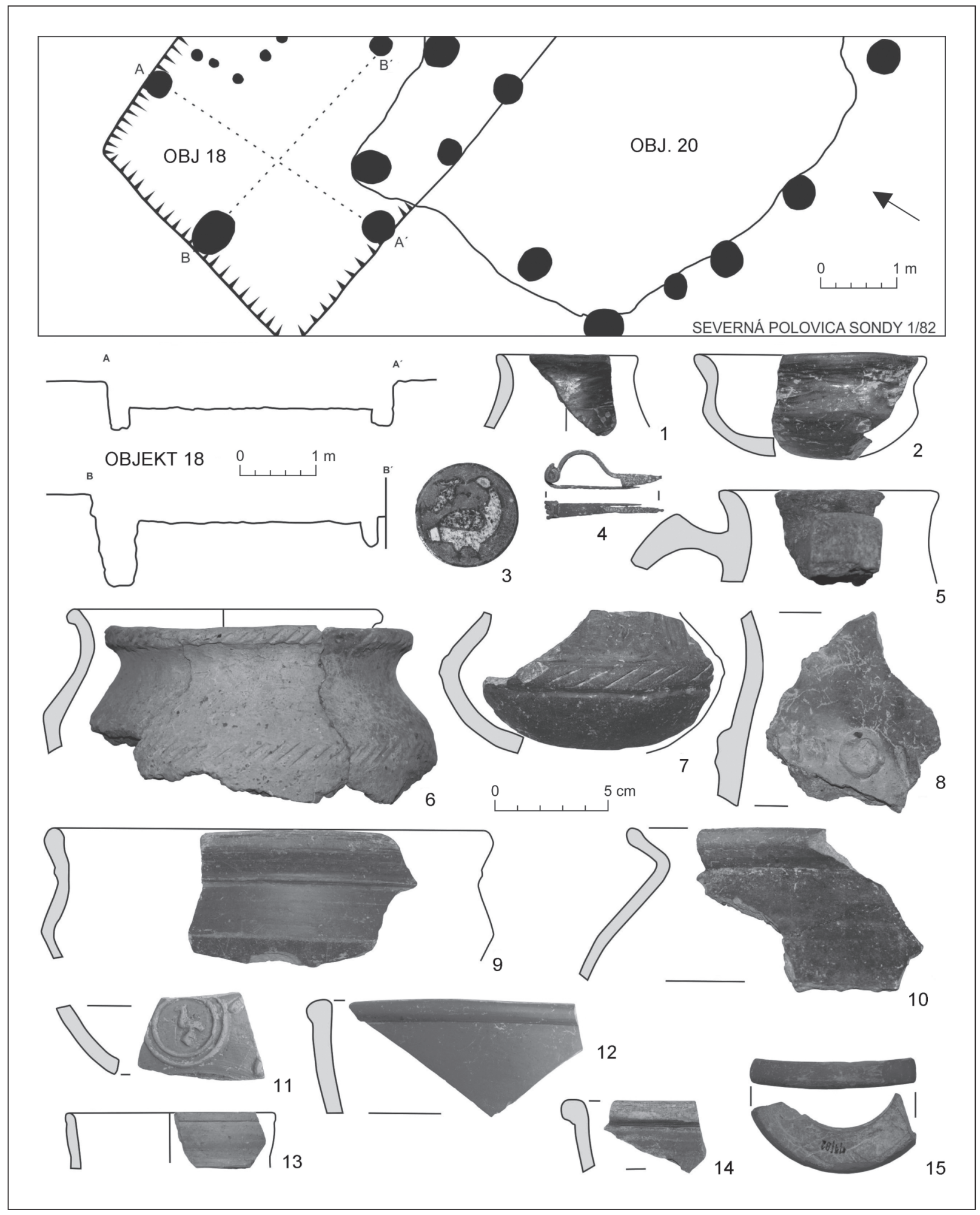

Tab. IV. Trstené pri Hornáde, okr. Košice okolie. Pôdorysy objektov 18 a 20; výber nálezov z objektu 18. 


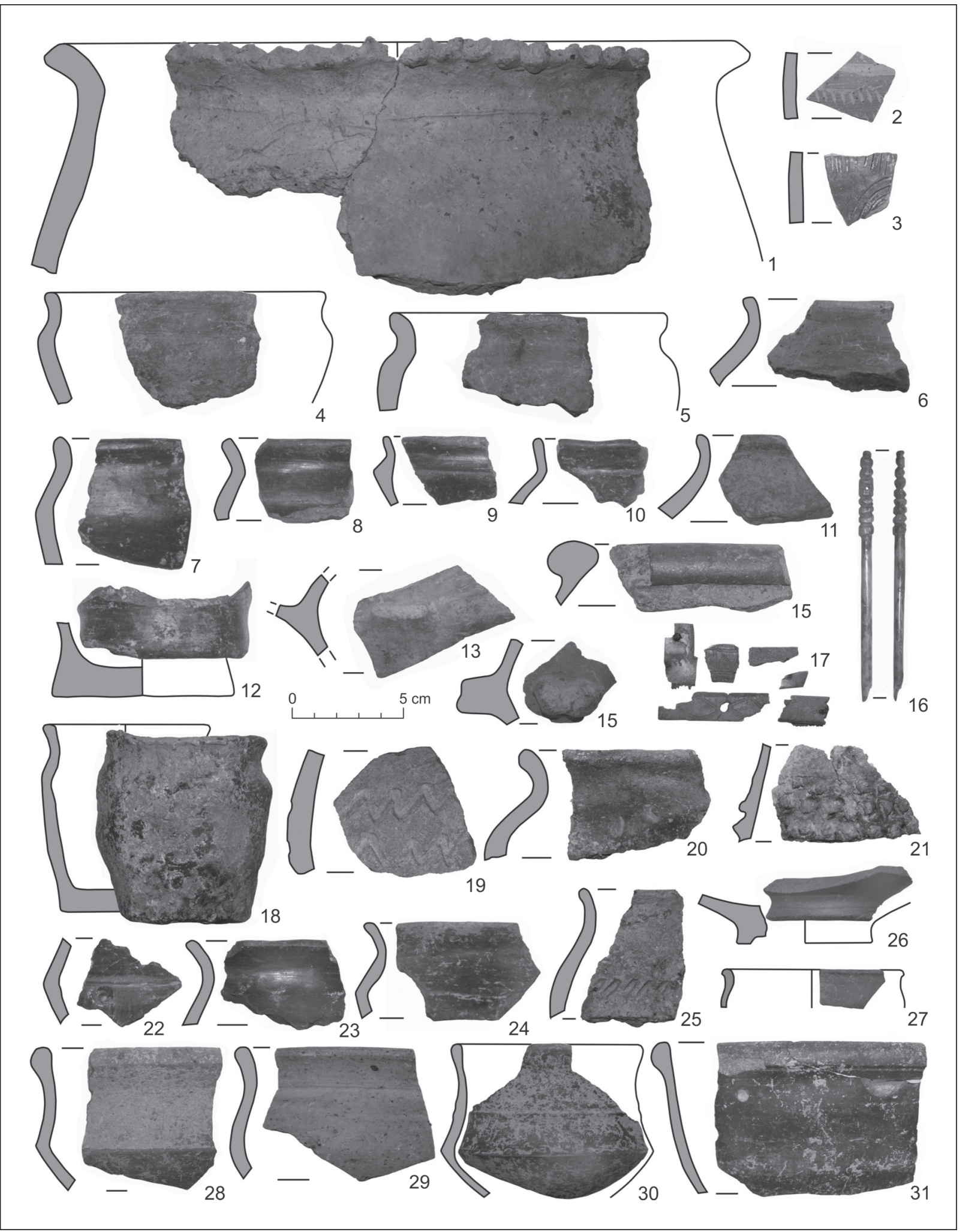

Tab. V. Trstené pri Hornáde, okr. Košice okolie. Výber nálezového materiálu z objektov. 1-16 - objekt 20; 17-31 - objekt 23. 


\section{LITERATÚRA}

Ardeleanu 2014

CGP

Čaplovič/Gašaj/Olexa 1978

Gabler 2002

Gabler 2012a

Gabler $2012 b$

Gabler 2017

\section{Gabler/Kellner 1994}

Gabler/Márton/Gauthier 2009

Jurečko 1981

Jurečko 1982a

Jurečko $1982 b$

Jurečko 1983

Kiss 1946-1948

Kellner 1981

Kol. AOVM 1984

Kuzmová 2014

Kuzmová/Rákoš 2016

Kuzmová/Roth 1988

Lamiová-Schmiedlová/Tomášová 1999 M. Lamiová-Schmiedlová/B. Tomášová: Nálezový horizont z prelomu doby rímskej a doby stahovania národov na viacvrstvovom sídlisku v Ostrovanoch. Slovenská archeológia 47, 1999, 75-132.

Mees 2002

Miroššayová 2015

O.

Pf.

Podgórska-Czopek 1999

$R i-F i$

M. Ardeleanu: Imports of terra sigillata in the Upper Tisza Basin. Statistic view and historical remarks. Anodos. Studies of the Ancient World 11/2011, 2014, 9-20.

J. A. Stanfield/G. Simpson: Central Gaulish Potters. London 1958.

D. Čaplovič/D. Gašaj/L. Olexa: Archeologické prieskumy na stavbách socializmu na východnom Slovensku. Archeologické výskumy a nálezy na Slovensku v roku 1977, 1978, 62-68.

D. Gabler: Terra sigillaták az aquincumi canabaeból. Budapest Régiségei 35, 2002, 227-265.

D. Gabler: Terra sigillaták Aquincum legkorábbi táborából és annak helyén emelt későbbi római épületekből. Budapest Régiségei 45, 2012, 111-150.

D. Gabler: A budaörsi terra sigillaták. In: K. Ottományi (ed.): Római vicus Budaörsön. Budapest 2012, 409-453.

D. Gabler: Die archäologischen Evidenzen der Markomannisch-Sarmatischen Kriege (166-180 n. Chr.) in den Donauprovinzen. Študijné zvesti AÚ SAV 61, 2017, 21-40.

D. Gabler/ H.-J. Kellner: Die Bildstempel von Westerndorf II. Helenius und Onniorix. Bayerische Vorgeschitsblätter 58, 1994, 185-270.

D. Gabler/A. Márton/E. Gauthier: La circulation des sigillées en Pannonie d'après les estampilles sur sigillées lisses de Gaule, de Germanie et de la région danubienne. Revue Archéologique de l'Est 58, 2009, 205-324.

P. Jurečko: Výsledky prvej etapy výskumu v Trstenom pri Hornáde. Archeologické výskumy a nálezy na Slovensku v roku 1980, 1981, 126-128.

P. Jurečko: Výskum v Trstenom pri Hornáde. Archeologické výskumy a nálezy na Slovensku v roku 1981, 1982, 138-140.

P. Jurečko: Výskumná správa z archeologického výskumu v Trstenom pri Hornáde v roku 1982. Archív Východoslovenského múzea v Košiciach. Košice 1982. Nepublikované.

P. Jurečko: Príspevok k riešeniu problematiky osídlenia východného Slovenska v dobe rímskej. Historica Carpatica 14, 1983, 277-384.

K. Kiss: A Westerndorfi terra-szigilláta gyár. Archaeológiai Értesítő 3, 1946-1948, 216-274.

H.-J. Kellner: Die Bildstempel von Westerndorf. Comitialis und Iassus. Rei Cretariae Romanae Fautorum Acta supplementa, Vol. 6. Augst/Kaiseraugst 1981.

Kolektív archeologického oddelenia Východoslovenského múzea v Košiciach: Pokračovanie výskumu v Trstenom pri Hornáde. Archeologické výskumy a nálezy na Slovensku v roku 1983, 1984, 112, 113.

K. Kuzmová: Roman pottery in Barbaricum: the case of terra sigillata in north-eastern part of the Carpathian Basin (Eastern Slovakia). Anodos. Studies of the Ancient World 11/2011, 2014, 171-184.

K. Kuzmová/J. Rákoš: Roman provincial products from the native settlement of the Przeworsk culture at Trstené pri Hornáde (Eastern Slovakia). Anodos. Studies of the Ancient World 12/2012, 2016, 163-171.

K. Kuzmová/P. Roth: Terra sigillata v barbariku. Nálezy z germánskych sídlisk a pohrebísk na území Slovenska. Materialia Archaeologica Slovaca IX. Nitra 1988.

A. W. Mees: Organisationsformen römischer Töpfer-Manufakturen am Beispiel von Arezzo und Rheinzabern: unter Berücksichtigung von Papyri, Inschriften und Rechtsquellen. Mainz 2002.

E. Miroššayová: Pohrebisko v Ždani v kontexte vývoja severného Potisia v dobe halštatskej. Nitra 2015.

F. Oswald: Index of Figure Types on Terra sigillata "Samian Ware“. Liverpool 1937, reprint London 1964.

H.-J. Kellner: Die Sigillata-Töpferei in Pfaffenhofen am Inn und ihr Formenschatz. Germania 42, 1964, 80-91.

J. Podgórska-Czopek: Wstępne opracowanie wyników badań osady kultury przeworskiej w Otałęży, woj. Rzeszów (stanowisko 1). In: Na granicach antycznego świata. Rzeszów 1999, 125-140.

H. Ricken/Ch. Fischer: Die Bilderschüsseln der römischen Töpfer von Rheinzabern. Bonn 1963. 
Rogers 1974

Thomas 1960

Varsik 2011
G. B. Rogers: Poteries sigillées de la Gaule centrale: Part I - Les motifs non figures. XXVIIIe supplement a Gallia. Paris 1974.

S. Thomas: Studien zu den germanischen Kämmen der römischen Kaiserzeit. Arbeitsund Forschungsberichte zur sächsischen Bodendenkmalpflege 8. Leipzig 1960, 54-215.

V. Varsik: Germánske osídlenie na východnom predpolí Bratislavy. Sídliská z doby rímskej v Bratislave-Trnávke a v okolí. Nitra 2011.

\title{
Terra sigillata in the context of a Przeworsk culture settlement at Trstené pri Hornáde
}

\author{
Klára Kuzmová - Ján Rákoš
}

\author{
Summary
}

The Przeworsk culture settlement at Trstené pri Hornáde (in the district of Košice okolie) dating from the $2^{\text {nd }}$ to the $5^{\text {th }}$ century was investigated in 1980-1984 (Jurečko 1981; 1982a; 1983; Kol. AOVM 1984). Excavated finds included several Roman provincial products (pottery, terra sigillata, brooches, coins; summarised in Kuzmová/Rákoš 2016) dating from the second half of the $2^{\text {nd }}$ century to the first half of the $3^{\text {rd }}$ century. The terra sigillata has been partially published earlier (Jurečko 1983, 291, 304, fig. 24: 3; 40: 3; 42: 5; 47: 4-6, 8, 11; 55: 2; Kuzmová 2014, 172, 173, tab. 1; 2; Kuzmová/Rákoš 2016; Kuzmová/Roth 1988, 113, 114, fig. 26: 8-11; see also Ardeleanu 2014, 12, tab. 1) and has currently been reevaluated as part of a complex new treatment of the settlement.

The new analysis showed that terra sigillata comes from four production centres (Lezoux, Rheinzabern, Westerndorf and Pfaffenhofen), and most likely found its way to this part of Barbaricum through Pannonia. It consists almost exclusively of fragments of decorated bowls (Drag. 37, alternatively 30), with only one find of Central Gaulish plain ware (Drag. 33).

Among the earliest finds is terra sigillata from Central Gaul (7 pcs $-25 \%$ of all finds; Cat. No. 1-7; Pl. I: $1-4)$ dating from the second half of the $2^{\text {nd }}$ century. Of particular significance are the products of Cinnamus and Albucius from Lezoux (Cat. No. 1-4; Pl. I: 1-4), attested also in Pannonian destruction layers related to the Marcomannic wars (Gabler 2002, 230; 2012a, 123; 2017, 31, fig. 10). The most abundant are the products of Rheinzabern (14 pcs - 50 \%); more than half of them (9 pcs) have known producers, but their dating is rather broad (Cat. No. 8-22; Pl. I: 5-12; II: 1, 2). Some of the finds date to the period of the Marcomannic wars (Cobnertus, Cerialis; Gabler 2017, 31, fig. 10), but products from the Severan period preponderate (Mees 2002, 323, 324, 329-332, 336, 337, 341-343, 346-348, 350; Gabler 2012a, 124-126; Gabler 2012b, 422-435). Five fragments (18 \% - Cat. No. 23-27; Pl. II: 3-5) from the Severan period have been attributed to the potter's centre in Westerndorf. The products of Comitialis, dated between the end of the $2^{\text {nd }}$ and the beginning of the $3^{\text {rd }}$ century, outnumber the products of Helenius from the first third of the $3^{\text {rd }}$ century. The latest finds include the only decorated fragment from Pfaffenhofen (3.5 \% - Cat. No. 28; Pl. II: 6; IV: 11), which was produced by Helenius in the first third of the $3^{\text {rd }}$ century.

In terms of the settlement context, terra sigillata is associated with three stratigraphically defined layers and with five structures. The finds from layers (17 pcs) outnumber the finds from structures (11 pcs). Terra sigillata found in the surface layer and in two subsequent layers (A and B) is typologically quite diverse, and its dating is broad. Each of the layers contains products from Lezoux, Rheinzabern and Westerndorf, broadly dated between the second half of the $2^{\text {nd }}$ century and the first third of the $3^{\text {rd }}$ century, i.e. from the Antonine/Late Antonine to the Severan period (Table 1).

The second group of finds derives from structures of different types, function and dating: from the Early to the Late Roman period, or even as late as to the beginning of the Migration period (Table 2). Structure 13 (storage pit) has been dated to the Early Roman period on the basis of native pottery. This, however, does not correspond with the dating of terra sigillata (one fragment, Westerndorf, Comitialis; Cat. No. 23), which was set between the end of the $2^{\text {nd }}$ century and the beginning of the $3^{\text {rd }}$ century, with most of it dating to the Severan period.

Two structures (6 and 18) have been broadly dated to the B2/C1 and B2/C1-C2 stages of the Roman period. Structure 6 was originally published as a single-chambered pottery kiln, but according to the new analysis it seems to be a superposition of two pits. This context produced only one fragment of terra sigillata from the period between the end of the $2^{\text {nd }}$ century and the beginning of the $3^{\text {rd }}$ century (Rheinzabern, Belsus I; Cat. No. 13; Pl. I: 10; III: 11). Its dating corresponds in part with the dating of the other finds (exclusively native pottery), which place the structure broadly to the B2/C1 stage of the Roman period (Pl. III: 1-11). Structure 18 with a posthole construction is interpreted as a house. Three finds of terra sigillata were found here, originating from three or four production centres (Central Gaul/Lezoux, Rheinzabern or Westerndorf and Pfaffenhofen; Cat. No. 5; 22; 28; Pl. II: 6; IV: 11, 12, 15). The broad dating of these finds 
to the period between the second half of the $2^{\text {nd }}$ century and the first third of the $3^{\text {rd }}$ century partially corresponds to the dating of the structure to the B2/C1-C2 stages of the Roman period, based on the other finds. They include mostly pottery of the Przeworsk culture, but also pottery with decorative elements known from the Quadi and Dacian contexts, as well as Pannonian pottery (Pl. IV: 1, 2, 5-10, 13, 14). Among metal objects two bronze brooches are important - an enamelled plate brooch and a brooch with a pointed foot, group Almgren VI (Pl. IV: 3, 4). It should be mentioned that structure 18 was situated in superposition with structure 20 (a house dating to the B2/C1 stages), which did not contain terra sigillata, but did contain similar finds of native pottery. Therefore, it cannot be ruled out that the inventories of the structures were partly mixed (Pl. V: 1-16).

Structure 16 (a semi-subterranean house) was dated to the C1-C2 stages of the Roman period. It produced three fragments of terra sigillata from Rheinzabern dating between the second half of the $2^{\text {nd }}$ century and the first third of the $3^{\text {rd }}$ century (Cat. No. 17, 18, 21; Pl. II: 2; III: 19-21). Their dating partly corresponds with that of the structure, i.e. the Late Roman period (stages $\mathrm{C} 1-\mathrm{C} 2$ ) based on other relevant finds. Besides native pottery, these include a bronze brooch with a returned foot (Pl. III: 12-18).

Structure 23, probably a house, dates to the latest phase of the settlement (stages C3-D). It produced three fragments of Rheinzabern terra sigillata, only one of which is dateable (Verecundus I, Late Antonine and Severan period). The other two fragments date broadly between the second half of the $2^{\text {nd }}$ century and the first third of the $3^{\text {rd }}$ century (Cat. No. 16, 19, 20; Pl. II: 1). In this case, there is a considerable time gap between the dating of terra sigillata and that of the other finds from this structure. The latter date between the Late Roman period and the beginning of the Migration period (stages C3-D) and include mainly fragments of the native and Roman provincial pottery, as well as fragments of a bone comb of Thomas III type (Thomas 1960, 104-114; pl. 5: 17-31).

Terra sigillata from the settlement at Trstené pri Hornáde represents the largest collection of this pottery from the territory of present-day eastern Slovakia (28 pcs). A comparison between the finds from the settlement area and those from the adjacent part of Barbaricum shows certain particularities. In both cases the products from Rheinzabern are clearly predominant, their proportion being somewhat higher at Trstené pri Hornáde (50:46\%). In the case of Westerndorf, the ratio is almost balanced (18:20\%). The differences were greater with the products from Lezoux and Pfaffenhofen: while the proportion of terra sigillata from Lezoux is much higher on the studied settlement than on the rest of eastern Slovakia (25:6\%), the opposite is true for the products from Pfaffenhofen (3.5: $20 \%)$. This can primarily be associated with the intensity of contacts between the Romans and the native population, and with the particularities of exchange and trading relations, as well as other relations, in the initial and final periods of the influx of these pottery products, i.e. in the third quarter of the $2^{\text {nd }}$ century (Lezoux) and in the second quarter of the $3^{\text {rd }}$ century (Pfaffenhofen). Despite this, the periods of occurrence of terra sigillata at Trstené pri Hornáde and in the adjacent area of eastern Slovakia are roughly identical - terra sigillata dates between the second half of the $2^{\text {nd }}$ and first half of the $3^{\text {rd }}$ century, with most of it dating to the Severan period.

Table 1. Trstené pri Hornáde, Košice okolie district. Overview of terra sigillata from settlement layers.

Table 2. Trstené pri Hornáde, Košice okolie district. Overview of terra sigillata from settlement structures.

Pl. I. Trstené pri Hornáde, Košice okolie district. Selected finds of terra sigillata. 1-4 - Central Gaul, Lezoux; 5-12 Rheinzabern.

Pl. II. Trstené pri Hornáde, Košice okolie district. Selected finds of terra sigillata. 1-2 - Rheinzabern; 3-5 - Westerndorf; 6 - Pfaffenhofen.

Pl. III. Trstené pri Hornáde, Košice okolie district. Selected finds from structures. 1-11 - structure 6; 12-21 - structure 16. Pl. IV. Trstené pri Hornáde, Košice okolie district. Ground plans of structures 18 and 20; selected finds from structure 18. Pl. V. Trstené pri Hornáde, Košice okolie district. Selected finds from structures. 1-16 - structure 20; 17-31 - structure 23.

Translated by Lubomíra Kuzmová

prof. PhDr. Klára Kuzmová, CSc.

Trnavská univerzita $\mathrm{v}$ Trnave

Katedra klasickej archeológie

Hornopotočná 23

SK - 91843 Trnava

klara.kuzmova@truni.sk
Mgr. Ján Rákoš

Východoslovenské múzeum Košice

Námestie Maratónu mieru 2

SK - 04001 Košice

jan.rakos@vsmuzeum.sk 
